\begin{tabular}{|c|c|}
\hline \multirow{3}{*}{ 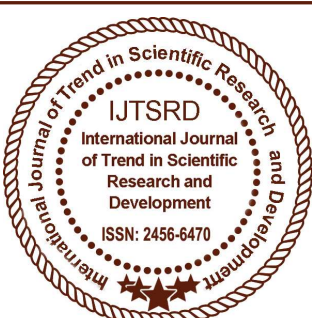 } & $\begin{array}{l}\text { International Journal of Trend in Scientific } \\
\text { Research and Development (IJTSRD) }\end{array}$ \\
\hline & International Open Access Journal \\
\hline & ISSN No: 2456 - 6470 | www.ijtsrd.com | Volume - 2 | Issue - \\
\hline
\end{tabular}

\title{
Solid Waste Management in Villages: A Review
}

\author{
Mr. Chavan M. C., Mr. Bhosale S. M., Mr. Sutar P. D. \\ Environmental Science and Technology, Department of Technology, \\ Shivaji University, Kolhapur, Maharashtra, India
}

\begin{abstract}
In numerous nations strong waste administration is missing, because of expanding underway of strong waste it leads destructive infections. After reviewing lots of international research articles the current scenario can be controlled by adopting a proper management system. Waste generation, gathering, transportation, isolations, recuperation and reuse, transfer this are the key factor in the waste management framework keeping in mind the end goal to lessen and reuse the strong waste in rustic and urban regions. It incorporates transfer of strong waste in a financially savvy way, utilizing waste to vitality clean systems, fertilizing the soil of natural waste and, landfill procedure.
\end{abstract}

Keywords: Solid waste, composting, waste to energy, sanitary landfilling, recycling

\section{INTRODUCTION}

In many parts of India solid waste is a major issue and the management of solid waste is not properly conducted.

Following are the functional elements of solid waste:-
Typical SWM System: Functional Elements

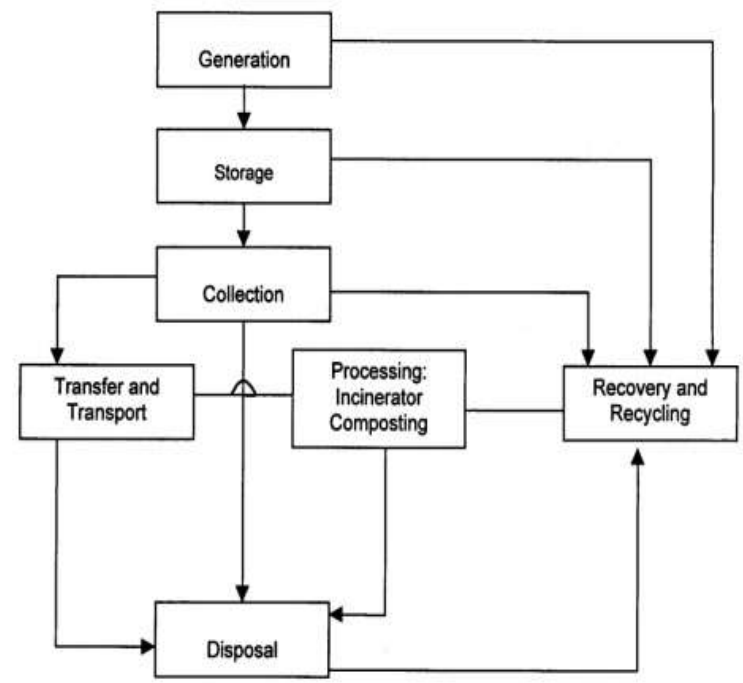

Orderly control of generation, accumulation, storage, transport, source detachment, handling, treatment, recovery, and transfer of strong waste called as solid waste management. Moreover, the solid waste is improperly treated and disposed in open land or open dumping is adopted. Harmful gases such as Methane, carbon monoxide, $\mathrm{Co} 2$, and nitrous oxide are generated from such kinds of disposal systems [8]. The essential goal of this management system is to gather the solid waste and isolate the loss at the source itself into dry and wet waste. The wet waste can be utilized as steers expenses if gathered before disintegration of vegetable waste or it can be utilized as an composition material. The dry waste can be reused or recovery. The auxiliary target is to gather and transport the solid waste. At the transfer can be made into move for such waste which can't be recycled or reused. Solid waste relies on the group and their way of life, populace propensity and 
occasional variety. Open dumping causing ground water pollution and surface bodies disease. Land likewise causing an immense harm lessening the sustenance level of land and causing air contamination if fizzle happens. The daily waste if not properly disposed of can lead to a serious problem related to public health and affects the aesthetics.

\section{LITERATURE SURVEY}

\section{Rashmi Shah, U.S. Sharma and AbhayTiwari [1]}

In this paper, solid waste management in an aggregation of six villages near Tekanpur area on NH-75 has studied. Street sweeping, grass cutting, agricultural waste etc. contribute most generation of waste. Water and soil pollution may cause due to uncontrolled dumping in this villages. Also, these may cause an adverse effect on public health \& environment. So to overcome these circumstances vermicomposting is proposed.

\section{Suraj A. Sutar and Sagar M. Gawande [2]}

In this, they presented that in rural areas of India solid waste management in the major problem and improper management of solid waste cause impact on environment and inhibitions. About 80 to $90 \%$ of MSW is disposed in open dumps causing environmental and health problem. To overcome problems in rural areas review of the various characteristics, generation, collection, segregation, transportation, disposal and other treatment technologies of solid waste management is done. With the help of GIS software, current systems of current solid waste management systems and problems are found out. Various technologies along with advantages and disadvantages are reviewed. The study is concluded with beneficial suggestions to encourage researchers to work towards the further improvement of the present system.

\section{S. Kadam and S.S. Sarawade [3]}

This paper states that in Indian metros and rural areas solid waste management becomes a critical issue. As the rate of generation is high it is a challenge for developing countries. Any development and change of lifestyle of the urban people attract the rural people leading to generate village solid waste. Rapid industrialization \& technical societal developments led to the high generation of solid waste.
Environment pollution likeair pollution, water pollution, and soil pollution occurs due to waste generated at rural places. Hence there is an urgent need for the efforts to overcome these problems in rural and urban areas. This paper deals with the problems associated with the management of solid waste and the options for treatment and designing a system for treatment of solid waste with eco-friendly. Solid waste management becomes a critical issue in Indian metropolitan cities as well as rural areas. As the rate of generation of waste is very high it is a challenge for the authorities in developing countries. The impact of urban area's culture on the rural areas (villages) and improvement in paying capacity of rural people causes more solid waste generation in the villages. Any development and change of lifestyle of the urban people attract the rural people leading to generate village solid waste. High waste generation rate is due to rapid industrialization \& technical societal developments. Waste generated at rural places creates major problems to environment pollution i.e. air pollution, water pollution and soil pollution. Now a day presently it is not only the urban problem but also the village problems too. Hence there is urgent need to solve these problems. This paper focuses on the problems related to the management of solid waste and the options for treatment and designing a system to treat solid waste in environmental friendly approach effectively.

Sources of VSW in Indian Villages

\begin{tabular}{|l|l|l|}
\hline Sources & $\begin{array}{l}\text { Typical Waste } \\
\text { generation }\end{array}$ & Components \\
\hline Industrial & $\begin{array}{l}\text { School, small } \\
\text { hotels, } \\
\text { markets, office } \\
\text { building. Small } \\
\text { hospitals. }\end{array}$ & $\begin{array}{l}\text { Paper, cardboard, } \\
\text { plastic, wood, food, } \\
\text { waste, glass, metal, } \\
\text { Thermocol }\end{array}$ \\
\hline Residential & $\begin{array}{l}\text { Single and } \\
\text { multifamily } \\
\text { dwellings }\end{array}$ & $\begin{array}{l}\text { Food waste, garbage, } \\
\text { paper, cardboard, } \\
\text { plastic, textiles, } \\
\text { glass, metal, ash, } \\
\text { special waste, } \\
\text { Leather, rubber, } \\
\text { Earth ceramics. }\end{array}$ \\
\hline Drainage & Public, Natural & Mud, Silica, Earth. \\
\hline Agriculture & $\begin{array}{l}\text { Farmers, } \\
\text { Animals }\end{array}$ & $\begin{array}{l}\text { Wood, Earth, Cow } \\
\text { dung, Animal waste, } \\
\text { leaves, grass, cattle } \\
\text { food waste. }\end{array}$ \\
\hline
\end{tabular}




\section{Mr. Priyank Shah, Dr.V.M. Patel, Patel Dhrumit and Patel Brijesh [4]}

This paper represents solid and liquid waste management in of seven villages. The qualities of both solid \& liquid wastes are increasing day by day and if the wastes are disposed on open and in an uncontrolled manner these may cause an adverse impact on public health \& environment. Therefore, the solid wastages are still a major problem in these rural areas. To solve these problems, we have implemented vermin composting.

\section{M.P. Joshi, S. B. Patil and K. Mourya [5]}

Nowadays, we are facing problems regarding the management of waste generated daily. This waste includes solid waste from various zones like industrial zone, commercial zone and residential zone. Among these waste from residential zone should be considered to disposeofdaily as it creates problems to public health, affects the aesthetics and environment. This paper presents the current status of solid waste management on dumping ground in Mumbai region and also suggests some methods to control them. Immediate steps for management of this waste will reduce the water, air, soil pollutions and health hazards.

\section{Mr. Kale Tejash Sunil and Dr. A. C. Attar [6]}

In this paper,author describes solid waste management in Gotkhindi village near Islampur. The waste is dumped openly and no data is available regarding generation of waste, so it is difficult for rural local bodies to manage solid waste in this village. Waste samples collected from a dump site analyzed for physical characterization which confirms its suitability for applying the biological method of composting. For composting and land filling waste characterization highlights the importance of waste segregation. The most common practice of waste is open dumping which causes pollution. If the wastes are disposed on open land it may cause an adverse impact on public health \& environment. These are problems regarding disposing of solid waste in rural areas. Hence to overcome these problems Bangalore method of composting is implemented.

\section{Abduli, M. A., Samieifard, R. and Jalili Ghazi Zade and M. [7]}

The province of Bushehr is located in southern area of Iran and north of Persian Gulf. The aim of this research was the management of solid waste in Bushehr villages. 21 villages scattered all over the province were selected. Field survey showed that about 640-650 grams of residential solid waste per capita is generated in selected villages every day. There are 322 shops in chosen villages and total amount of commercial waste is about 3560 kilograms per day. The average amount of medical waste is about 7.5-8.0 kilograms per hygienic unit. Waste Composition of various materials is given in below table:

\begin{tabular}{|l|c|}
\hline WASTE MATERIAL & $\begin{array}{l}\text { WASTE COMPOSITION } \\
\text { IN PERCENTAGE }\end{array}$ \\
\hline Putrescible materials & $40-45$ \\
\hline $\begin{array}{l}\text { Construction and } \\
\text { demolition }\end{array}$ & $10-12$ \\
\hline Paper and cardboard & $8-9$ \\
\hline Plastics ntific & $8-9$ \\
\hline Wood nd & $6-7$ \\
\hline Metalent & $5-7$ \\
\hline Glass & $5-6$ \\
\hline Rubber and leather & $5-6$ \\
\hline Textile & $4-5$ \\
\hline
\end{tabular}

According to this study, the main obstacle to recycling program is the impartial collection of waste in the rural area. It is recommended that for the first five-year program, source separation includes degradable matter and dry wastes (paper, plastics and metals). Source separation of other components such as wood, rubber, glass, and textile can be carried out in the second five-year program. From the economical point of view, incineration with energy recovery cannot be a good alternative for rural waste disposal. Due to the low volume of degradable matter, land availability with low cost and easy access to the labor force in rural areas, low-cost technology composting is recommended. The quantity of waste generated in each village is not 
sufficient to be managed separately, so waste from adjacent villages is managed combine.

\section{CONCLUSION}

According to above paper, it is seen that strong waste management is significant issue and impact on human life and condition. Thus, appropriate waste management to be done for the most part in rustic as waste management in shameful there. It can be accomplished by accumulation and capacity, isolation at sources, legitimate transportation, treatment and safe transfer of strong waste and furthermore to make the mindfulness.

The perfect route is to lessen, to reuse and to reuse suggests usage of 3R thought and changing over waste to imperativeness, treating the dirt and clean land filling. As cremation create dangerous gases and can't be signed if squander contains dampness, so Bangalore fertilizing the soil technique can be embraced.

\section{REFERENCES}

1. Rashmi Shah, U.S. Sharma and Abhay Tiwari, "Sustainable Solid Waste Management in Rural Areas",International Journal of Theoretical \& Applied Sciences,4(2): 72-75(2012).

2. Suraj A.Sutar and Sagar M. Gawande, "Solid Waste Management in Rural Areas emerging towards growth centre through GIS systemMahalung, Solapur", International Journal of Science and Research (IJSR),Volume 4 Issue 7, July 2015.

3. M. S. Kadam and S. S. Sarawade, "Sustainable Solid Waste Management for Rural Area",IOSR Journal of Environmental Science, Toxicology and Food Technology (IOSR-JESTFT),Volume 10, Issue 8 Ver. II,PP 133-137,(Aug. 2016).

4. Mr. Priyank Shah, Dr.V.M. Patel, Patel Dhrumit,and Patel Brijesh, "Solid and Liquid Waste Management in Rural Areas",IJIRST International Journal for Innovative Research in Science \& Technology, Volume 1,Issue 12,(May 2015).
5. M.P. Joshi, S. B. Patil and K. Mourya, "Solid Waste Management on Dumping Ground in Mumbai Region - A Study",International Conference on Green Computing and Technology,(2013).

6. Mr. Kale Tejash Sunil and Dr. A. C. Attar, "Study and Analysis of Solid Waste Management Challenges and Options for Treatment (Indian Villages)",IOSR Journal of Mechanical \& Civil Engineering (IOSRJMCE),PP 15-22,March 2016.

7. Abduli, M. A., Samieifard, R. and Jalili Ghazi Zade and M, "Rural Solid Waste Management",Int. J. Environ. Res., 2(4): 425 430,(2008).

8. Aliakbar Mohammadi, Abdoliman Amouei,Hosseinali Asgharnia, Hourieh Fallah, ZeinabGhanami "A Survey on the Rural Solid WastesCharacteristics in North Iran (Babol)",Environmental Research And Technology,ISSN22490256, 2(3): 149153(2012).

9. Zaveri C. "Gorai Dumping Ground - An Urban Rejuvenation Project"2014. 